\title{
FRANCHISE CONTRACT AND GOOD FAITH
}

\author{
Ergysa IKONOMI \\ Lecturer at "Ismail Qemali" University of Vlora, ALBANIA \\ ergysa83@yahoo.com
}

\section{DOI:10.5901/mjss.2014.v5n22p313}

\begin{abstract}
Franchise is a widespread business model in countries with developed economies. Although that in Albania there are few franchising relations, the Albanian Civil Code provides franchising as a contract. The franchise contract is a binding agreement where the franchiser grants the franchisee the right to use the trademark and the operating system of the franchiser, mutually fulfilling rights and duties derived by this contract. The most important duty of the franchiser is to make available to the franchisee a standardized set of immaterial rights, models, charts, profit, organization and trade ideas, and other appropriate knowledge for the development of trade. During the negotiations, the parties have to show each other the commercial affairs conditions dealing with the franchise agreement and the franchise obligations particular program. The information during the negotiations must be confidential and such must remain, even if the contract is not concluded. The Albanian Civil Code provides that in general during the contract negotiations, the parties must act in good faith towards each other. In case of franchise contract the good faith is specifically required by law, due to the fact that the parties normally provide each other with important and economical valuable information. The aim of this paper is to realize an overview of a new contract, as franchising and its importance in economic relations. This paper will clarify the Albanian legal provisions on franchise contract, the rights and duties of each party. It will be highlighted the role of good faith in negotiations, how the parties must act and the possibility to compensate potential damages. It is about one principle, the Good Faith Principle, that Civil Law jurisdiction and Common Law jurisdictions have generally two different approaches. The paper will show the changes in legal provisions of some European countries regarding good faith in franchise contracts.
\end{abstract}

Keywords: franchise contract, good faith, Civil Law, Common Law, negotiations

\section{Introduction}

Franchise is a widespread business model in countries with developed economies. It is considered as a business opportunity, a successful one. It had became popular from the mid of 20th century in North America. But the origin of franchise goes back to middle ages.

The word "franchise" derives from old French and means "privilege" or "freedom". In the middle ages a franchise was a privilege or a right and the local sovereign or lord would grant the right to hold markets of fairs, to operate the local ferry or to hunt in his land. (Rogerson, 2008) In essence, the sovereign gave an individual or group of individuals the monopoly rights over a particular activity in a particular location for a certain period of time. In most cases, the grantee was required to make a payment to the sovereign power for this right or privilege, usually in the form of a share of the product or profit. (Blair \& Lafontaine, 2005)

The Singer Company, which produced sewing machines, created the concept of franchise business in 1850's. The Sewing Machine Combination became the first patent pool in the United States, dividing the distribution rights among the manufactures. The franchisees were granted worldwide right, territories, and exclusive rights to sell and service their machines. (Duening, Hisrich \& Lechter, 2010)

Legislations all over the world have provisions to regulate franchise as a contract, as an economic relationship. Franchising, compared with other contracts, can be considered a new contract, but these last decades have shown an increasing use of it.

The current Albanian Civil Code, which entered in force in 1994, has specific provisions on realizing the franchise contract, although in Albania there are few cases of franchise. It is about regulating a binding agreement which is negotiated confidentially and in good faith. 
The aim of this paper is to clarify this "new", atypical contract, its economic value, the manners and the behaviors of the parties. It is important to pay attention to franchise contract, according to the global trend of using it more often.

The paper will be realized divided into two main parts. In the first part of the paper it will be shown an overview of what the Albanian Civil Code provides on franchise contract. This part will be completed with brief descriptions about the legal regulations of the franchise contract by some European countries legislation and USA legislation, in order to show up the differences and to analyze them.

In the second part of the paper the attention will be focused on good faith, specifically required by law, during the negotiations of the franchise contract. The "duty" of good faith will be analyzed by taking in consideration the different approaches to this principle by Civil Law jurisdiction and Common Law jurisdictions. It will be put face to face some European countries legislations for understanding the value of Good Faith Principle in this kind of contract.

\section{Franchise Contract}

As an agreement that promises success, franchise is an economic relationship with mutual benefits, both for the franchisor and the franchisee. In the last decades the franchise relationship has become important as a business tool.

The principal ingredient in most franchise contracts is the franchisee's right to use a national brand name in exchange for a share of profits to the franchisor. (Mathewson \& Winter, 1985)

The franchisee's advantage is quite clear: the use of a well known trademark and operating system of the franchisor. The franchisee benefits the support, the information, the experience and appropriate knowledge from the franchisor. The franchisee foresees that the business to be successful, as it has resulted to be such for the franchisor. So, there is less work to do, just to withstand and perform daily duties regarding the business. The customers are almost certain. The business is launched advantaged because of the national or international marketing, which this new business normally cannot afford.

The main benefits of the franchisor are the entry fee, as a fix amount of money related to the economic value and to the potential development of the system, which is paid by the franchisee and the royalty payment, set as a percentage of profits of the franchisee. There are moments of business development, when the franchisor may not be able to invest. So he uses his well known trademark and operating system, in order to expand nationally or internationally quickly and with less cost. The franchisor has the right to choose the franchisee, taking into consideration his qualification, but certainly the location where the franchise right will be used, which should constitute a geographical intention of the franchisor for further expansion.

The Albanian legislation provides the franchise relationship as a contract which contains a continuous obligation relationship to which independent enterprises are obliged to each other to jointly promote and develop trade and service delivery, implementing specific obligations. (The Albanian Civil Code, art. 1056)

The Italian Law 129 06.05.2004 "Rules on the regulation of franchising" recognizes franchising as a contract that can "be adopted in any economic field" (The Italian Law 129 06.05.2004 "Rules on the regulation of franchising", art. 1) and gives a detailed definition about it.

There is no legal definition of a franchise in French law. The French Franchise Federation refers to the definition of the European Code of Ethics for Franchising, which may be taken into consideration by French courts. (Schulte, 2014)

"Franchising is a system of marketing goods and/or services and/or technology, which is based upon a close and ongoing collaboration between legally and financially separate and independent undertakings, the Franchisor and its individual Franchisees, whereby the Franchisor grants its individual Franchisee the right, and imposes the obligation, to conduct a business in accordance with the Franchisor's concept.

The right entitles and compels the individual Franchisee, in exchange for a direct or indirect financial consideration, to use the Franchisor's trade name, and/or trade mark and /or service mark, know-how, business and technical methods, procedural system, and other industrial and /or intellectual property rights, supported by continuing provision of commercial and technical assistance, within the framework and for the term of a written franchise agreement, concluded between parties for this purpose."(The European Code of Ethics for Franchising, 1)

There is no legal definition or specific law governing franchising in the UK. Like the French Franchise Federation, even the British Franchise Association has adopted the definition of the European Franchise Federation. Common law would regard 
a franchise agreement as a complex, hybrid contract including various elements from other commercial contractual arrangements. (Wormald \& Bond, 2014)

In USA, many states have franchise 'registration/disclosure' or franchise 'relationship' laws (or both) that define franchises. There are no federal franchise relationship laws of general application. However, certain industries are regulated by industry specific legislation. (Brennan \& Zeidman, 2014)

\section{Parties rights and obligations}

The franchise contract is an agreement that includes mutual obligations and responsibilities for the parties. The franchisor has the obligation to make available to the franchisee's standardized set of immaterial rights, models, charts, profit, organization and trade ideas, and other appropriate knowledge for the development of trade. Meanwhile, he is obliged to protect all the obligations program from infringement by third parties, constantly develop it and support its implementation by the franchisee with instructions, information and perfection. (The Albanian Civil Code, art. 1057)

By interpreting the above mentioned provision, arise the obligations of the franchisor. The provision listed and mentioned them generally. The franchisor has normally years of experience and considerable knowledge for the development of the trade. He has to help and assist continuously the franchisee and to consult him. The assistance, the help and the consultation may be given by the franchisor himself, or by other persons who work for him, who are trained and qualified enough. These are undoubtedly obligations, but can also be evaluated as forms that increase cooperation and communication between the parties.

The franchisor has the duty to fulfill the obligations program. "... In case that the rights would not exist or if the franchisor would violate other contractual obligations by fault, the franchisee has the right to reduce compensation. The reduced amount should be decided with competence through an impartial expert. The franchisee may require compensation of damages caused by the absence of the obligations program elements or by breach by fault of the contract by the franchisor." (The Albanian Civil Code, art. 1062) The duty to support the program implementation is expressed clearly, but it is important to understand "the continuity development" of the program. In an evolving economy, there is strong competition. The franchisor has to help the franchisee to face the competition and to minimize the losses, by developing the obligations program, adapting it to new economic situations. The franchisor also has to protect the obligations program from infringement by third parties.

The franchise contract is a contract which provides also obligations for the franchisee. "The franchisor is responsible for the existence of rights and knowledge of the obligations franchise program." (The Albanian Civil Code, article 1062) The franchisee has the duty to communicate with the franchisor, in order to get all the necessary consult and instructions to understand the way the business should be run. It certainly increases the chances to start a successful business. In order to achieve this goal, the franchisee and even his staff may need to be trained. "The franchisor may seek compensation for damage caused by breach of contract by fault, in particular by insufficient implementation of the obligations franchise program by the franchisee." (The Albanian Civil Code, article 1063)

The franchisee has the duty not to compete. According to the Albanian Civil Code: "to the franchisee can be imposed a ban of local competition for a time up to a year. If from the prohibition of competition results a reduction of his professional activity, an equal financial compensation is given to the franchisee, regardless the termination of contract." (The Albanian Civil Code, article 1061)

The franchise contract parties have also common obligations. "Even after the termination of the contract the parties have mutually obligation for a fair competition." (The Albanian Civil Code, article 1061)

In fact, each franchise contract must contain specific provisions according to the type of franchise, but even to what the parties have agreed.

The Italian law provides two articles referring to the obligations of the franchisor and the franchisee. There are some criteria to be fulfilled from the franchisor business to set a franchising network. The obligations of the franchisor are listed and expressed related to the content of the franchise contract. (The Italian Law 129 06.05.2004 "Rules on the regulation of franchising", art. 4) One of the franchisee obligations is "...to respect and have respected by his own personnel and collaborators, even after the contract termination, the strict confidentiality on the content of the activity operated in the franchise." (The Italian Law 129 06.05.2004 "Rules on the regulation of franchising", art. 4) As compared to the Albanian legislation, the Italian legislation provides an important element as a "must" in the content of the franchise contract. It is 
about the territory where the franchisee will operate or the territorial rights. (The Italian Law 129 06.05.2004 "Rules on the regulation of franchising", art. $1 \& 3$ )

There are no legal requirements by United Kingdom legislation for the franchisor before he may offer franchises, but the Code of Ethics imposes some, which are less comparing to the Italian legal requirements. Post-termination non-compete covenants are prohibited after the termination of an agreement, unless a franchisor's 'know-how' is dependent on them. However, this know-how is required to be classed as 'secret', which under its new definition in the block exemption is difficult for franchisors to prove. (Wormald \& Bond, 2014)

Comparing to the Italian legislation, there is no such legal or regulatory requirement that must be met before a franchisor may offer franchises, under French law. But, since a franchise is described by case law as the 'reiteration of a commercial success', the franchisor must be in a position to prove, prior to offering a franchise, that it has operated at least one similar commercial business in a manner and, for the time necessary to consider such business, as a success. (Schulte, 2014)

In US a franchisor must be in compliance with any applicable state registration and disclosure requirements before that franchisor may offer franchises.

\section{The franchise contract form}

"Franchise contract must be in writing specifying among other things a unanimous definition of mutual obligations of the parties, the duration of the contract and other essential elements of it. The text of the contract must contain a full description of the program and franchise obligations." (The Albanian Civil Code, art. 1059)

This shows that the law recognizes the obligation that the will of the parties, in the case of the franchise contract, to be expressed in a letter. Besides the essential elements, such as the determination of the parties, its object, the content of the contract requires more than setting out the rights and obligations of the parties. The legal provision requires that the text of the franchise contract to have detailed and complete description of the obligations and the franchise program. According to the type of franchise, the obligations program may not be part of the text of the contract, but placed as an annex to it, of course obligatory for implementation.

The Italian Law provides that the franchise contract "... must be stipulated in writing, otherwise it is null and void" (The Italian Law 129 06.05.2004 "Rules on the regulation of franchising", art. 3) Even "franchise agreements anterior to the entering into force of the present law... shall be formalized in writing..." (The Italian Law 129 06.05.2004 "Rules on the regulation of franchising", art. 9)

According to the United Kingdom legislation and French legislation all contracts and all contractual agreements related to the franchise relationship should be written. It is meant because the legislations provide even the appropriate language in which the contract will be drafted.

A franchise contract contains a lot of rights and obligations for the parties, referring to financial, advertising, payment, communication and control issues. The program also contains the procedures, the forms and the ways all the obligations should be fulfilled by the parties. That is why the franchise contract must be in writing.

\section{Good Faith in Franchise Contract}

Good Faith is usually required by people as to set a standard for good relationships. As a principle, good faith is recognized by the contract law and is required at pre - contractual phase. It is justified by the importance of this phase and by the uncertainty which accompanies it.

Generally, the Albanian legislation provides that: "Parties during the course of negotiations for the drafting of the contract must act in good faith towards each other". (The Albanian Civil Code, art. 674) The behavior of the parties must be in good faith, in order to avoid possible damages.

According to The Albanian Civil Code, article 675 "In case that a contracting party possesses professional knowledge and evokes the other side of her full confidence, it has an obligation to provide information and guidance in good faith." In specific contracts like franchising, the obligation of confidentiality is expressed clearly and is worth even if the contract is not concluded.

"At the completion of contract negotiations the parties should show each other the state of commercial affairs dealing with the franchise contract and particularly the franchise obligations program, and inform each other according to the principles 
of good faith. They are required to maintain the secrecy of confidential information, even if the contract is not concluded. (The Albanian Civil Code, art. 1058)

The pre-contractual phase carries the possibility of liability for the party which acts in lack of good faith. In the case of franchise contract the principle of good faith is expressly required during the negotiations. It is justified even by the important information that the parties give each other. Being combined with the request to maintain secrecy of confidential information, the provision makes clear the way the parties should behave. The conclusion or not of the franchise contract "has no importance". The confidential information is given during the negotiations. As this phase is uncertain for the final result, each party that does not act in good faith or does not maintains confidentiality "... is liable to compensate the damage. This right shall prescribe after three years from the date of the conclusion of negotiations." (The Albanian Civil Code, art. 1058)

The party that has participated in the negotiations may require payment of costs incurred by legal confidence in the conclusion of the contract, which was not concluded due to a deliberate behavior of the other party." (The Albanian Civil Code, art. 1058)

In Italy the Supreme Court (Corte Suprema di Cassazione) has expressed in September 2009 (Decision No. 20106, 18.09.2009 of the Italian Supreme Court) that the principle of objective good faith, as the mutual loyalty of conduct, should govern the formation, execution and interpretation of the contract and accompanies it at every stage. (Picierno, 2009)

The Italian Law provides the requirements of loyalty, fairness and good faith as a standard to the parties' behavior: "The franchisor must behave towards the prospective franchisee according to the standards of loyalty, fairness and good faith..." (The Italian Law 129 06.05.2004 "Rules on the regulation of franchising", art. 6, paragraph I), "The prospective franchisee must behave towards the franchisor in compliance with the standards of loyalty, fairness and good faith..." (The Italian Law 129 06.05.2004 "Rules on the regulation of franchising", art. 6, paragraph III)

The disclosure of information of the parties towards each other is substantial and inevitable for the realization of negotiations and the conclusion of the contract. Although the franchisor must justify to the prospective franchisee any possible failure in disclosing the information and data that had been requested by the franchisee, especially in case of objectively confidential information or if a disclosure would violate third parties rights.

Though the French Civil Code and the French courts have not given generally to good faith the same extension and the same importance, according to the franchise contract, the principle of good faith is present. Franchise agreements must comply with general principles of contracts and the franchisor is under a general obligation to contract in good faith which requires that the franchisor delivers any necessary piece of information during the course of the contractual relationships. The franchisor must act dutifully and in cooperation with the prospective franchisee. This implies disclosing clear and accurate information that would be of significance to the future franchisor, even if such information is not covered by the pre-contractual disclosure obligation. (Schulte, 2014)

The French Civil Code recognizes good faith as "a must" in performing a contract. "Agreements lawfully entered into take the place of the law for those who have made them.

They may be revoked only by mutual consent, or for causes authorized by law.

They must be performed in good faith." (The French Civil Code art. 1134) So, it should be accepted that the principle of good faith undoubtedly applies to franchise contracts.

The English contract law does not provide the duty to negotiate, interpret and perform a contract in good faith. The English law is based on liberal autonomy of the parties, to which an extreme approach is referred to a Latin maxim neminem laedit qui suo iure utitur (if you are exercising your right you are not harming anybody). As the parties design their contract they expect the legal system to give them tools in order to enforce what they have agreed, and not to be protected by the legal system. (Mitchell \& Powell, 2011) Referring to the franchise contract, there is no general obligation for parties to act in good faith towards each other. (Wormald \& Bond, 2014)

Although belonging to the common law system, the USA has adopted the good faith principle. In USA, courts in most states have consistently held that an implied covenant of good faith and fair dealing exists in commercial contracts, including franchise agreements. It varies from state to state how the principle of good faith is applied and in addition to several franchise-specific statutes, state law typically imposes a common law duty of good faith and fair dealing. The covenant generally provides that the parties to a contract must exercise their discretion as to the performance of their contractual obligations in a manner that is not inconsistent with the other party's reasonable business expectations and does not deprive the other party of the benefit of the contract. (Brennan \& Zeidman, 2014) 
Although the Albanian legislation and other European legislations provide explicitly the duty to behave in good faith during the negotiations phase of franchise contract, in fact it is clear that there is presence of good faith throughout the period that the franchise relationship continues and after that. Behaving in good faith should be understood to the continuous support of the franchisor towards the franchisee, to the interactively fulfillment of the obligations program, to the possibility of renewal of the franchise contract and the obligation of not compete.

\section{Conclusions}

In Albania franchise is almost unknown as an economic activity, regulated by law. The new Albanian Civil Code contains some provisions over franchise relationship, recognizing it as a contract.

Referring to those provisions, comparing to those of other European legislations, it should be said that the obligations of the parties in a franchise relationship are expressed generally, without listing a series of obligations of the franchisor or the franchisee. The same problem is also on the content of the contract. The European legislations which regulate franchise contract by specific law or by the Commercial Code express clearly the elements that the contract must mention e. g. the territory or the location where the franchisee has the rights accorded by the franchisor.

This paper claimed to give an overview of the way the franchise relationship is recognized and regulated as a contract and as such, to clarify the presence of the principle of good faith.

As Albania belongs to the Civil Law system, the good faith principle is considered as a general rule to be applied in each contract, as a set standard for the parties' behavior during each phase of the contract. Other countries, belonging to this system of law, like Italy and France through their legal provisions or by courts opinions and decisions, recognize the duty of good faith in contracts, especially in franchise contract.

The trend of recognizing good faith even by states which belong to the Common Law system is now clear. The USA recognizes good faith through the Uniform Commercial Code. Despite the fact that the application of this principle varies from state to state, generally the courts in most states have held that an implied covenant of good faith and fair dealing exists in franchise contracts. But, United Kingdom legislation expresses another approach to the application of good faith principle in contracts. The contract law does not provide the duty to negotiate, interpret and perform a contract in good faith, as is based on liberal autonomy of the parties. So even for the franchise contract there is no legal provision to obligate the parties to act in good faith.

Good faith is required in everyday life. But, as it is imposed by law, as a contract principle it becomes more important. The franchise contract, comparing to other types of contracts is considered new. It is complicated because this contract provides many obligations for the parties and it is specific because at every phase of contract there is a lot of information that the parties have to give to each other. The franchise contract actually means an agreement between two parties, who have not absolutely the same experience, knowledge and success. In that case the franchisee is "inferior" and can be easily misled. So, the presence of good faith, as a legal requirement means security and defines a behaviour standard, which avoids intentional damages.

\section{References}

Blair, R. D. \& Lafontaine, F. (2005). The Economics of franchising, 3. Retrieved from http://books.google.com

Brennan, M. G. \& Zeidman, P. F. (2014). United States. In P.F. Zeidman (Ed.), Franchise 2014, 190 - 199, London. Retrieved from http://www.franchise.org/uploadedFiles/F2014\%20United\%20States.pdf

Duening, T. N., Hisrich, R. D. \& Lechter, M. A. (2010). Technology Entrepreneurship: Creating, Capturing, and Protecting Value, 506. Retrieved from http://books.google.com

Mathewson, G. V. \& Winter, R. A. (1985). The economics of Franchise Contracts, Journal of Law and Economics, 28 (3), 504. Retrieved from http://www.sfu.ca/ wainwrig/Econ400/mathewson-winter85.pdf

Mitchell, S. M. \& Powell, E. J. (2011). Domestic Law Goes Global: Legal Traditions and International Courts, 40. Retrieved from http://books.google.com

Picierno, F. (2009). Freno della Cassazione ai comportamenti scorreti dei colossi economici, NOTA a Cass. Civ. III sez. 18 settembre 2009 n. 20106. . Retrieved from http://www. diritto.it/docs/28338-freno-della-cassazione-ai-comportamentiscorretti-dei-colossi-economici-nota-a-cass-civ-iii-sez-18-settembre-2009-n-20106?page=2 
Rogerson, A. (2008). Successfully buy your franchise, 27. Retrieved from http://books.google.com

Schulte, E. (2014). France. In P.F. Zeidman (Ed.), Franchise 2014, 62-68, London. Retrieved from http://www.franchise.org/uploadedFiles/F2014\%20France.pdf

Wormald, C. 7 Bond, D. (2014). United Kingdom. In P.F. Zeidman (Ed.), Franchise 2014, 184 - 189, London. Retrieved from http://www.franchise.org/uploadedFiles/F2014\%20United\%20Kingdom.pdf

Wright, Johnston \& Mackenzie, (2012). Franchising: the legal consideration, 9. Retrieved from http://www.wjm.co.uk/images/uploads/2012 Franchising - The Legal Considerations .pdf

The European Code of Ethics for Franchising

The Albanian Civil Code

The French Civil Code

The Italian Law 129 06.05.2004 "Rules on the regulation of franchising"

Decision No. 20106, 18.09.2009 of the Italian Supreme Court 